\title{
The management of Asherman syndrome in gynecology
}

\author{
Wachyu Hadisaputra, ${ }^{1}$ Yohanes Handoko ${ }^{2}$ \\ ${ }^{1}$ Department of Obstetrics and Gynecology, Faculty of Medicine, Universitas Indonesia, Cipto Mangunkusumo Hospital, Jakarta, \\ Indonesia \\ ${ }^{2}$ Faculty of Medicine, Universitas Indonesia, Cipto Mangunkusumo Hospital, Jakarta, Indonesia
}

\begin{abstract}
Abstrak
Sindrom Asherman adalah penyakit yang ditandai dengan terbentuknya perlekatan di rongga uterus. Kondisi ini umumnya disebabkan oleh trauma di endometrium yang terjadi setelah kuretase atau pasca persalinan dan dapat menyebabkan berbagai komplikasi seperti gangguan menstruasi, infertilitas, atau abortus berulang. Penanganan sindrom Asherman membutuhkan tindakan menyeluruh yang terdiri dari pencegahan, antisipasi, tatalaksana komprehensif, pengamatan berkala pada kehamilan berikutnya, dan evaluasi tatalaksana serta penyuluhan yang berkelanjutan. Seluruh aspek penanganan tersebut diringkas dengan PRACTICE (prevention, anticipation, comprehensive therapy, timely surveillance of subsequent pregnancies, investigation and continuing education). Tindakan pencegahan dan antisipasi yang dapat dilakukan antara lain mengurangi jumlah tindakan invasif seperti kuretase, terapi profilaksis adhesi seperti antibiotik dan estrogen pasca tindakan untuk pasien berisiko tinggi, serta penggunaan alat-alat operatif yang tidak melukai dinding rahim secara berlebihan. Tatalaksana komprehensif yang menjadi metode pilihan adalah lisis operatif dengan histeroskopi untuk memberikan penglihatan langsung ke lokasi adhesi. Pada pasien risiko tinggi yang merencanakan hamil kembali, untuk mencegah rekurensi pada kehamilan berikutnya harus dilakukan di rumah sakit dengan pemeriksaan penunjang yang lengkap. Pada akhirnya, tindakan evaluasi hasil operasi serta penyuluhan berkelanjutan mengenai prognosis pasien harus diberikan. (Med J Indones. 2013;22:121-6)
\end{abstract}

\begin{abstract}
Asherman syndrome is an acquired condition characterized by the formation of adhesions in the uterine cavity. This condition is often caused by trauma to the endometrium, which mostly happens after currettage or post-partum, and can produce several complications such as menstrual disturbances, infertility, or recurrent abortion. The management of Asherman syndrome requires complete actions which can be summarized with the acronym PRACTICE, consisting of prevention, anticipation, comprehensive therapy, timely surveillance of subsequent pregnancies, investigation and continuing education. The prevention and anticipation aspects can be performed through reduction of invasive methods of therapy such as currettage, prophylactic therapy for adhesions such as antibiotics and post-estrogen therapy for high risk patients, and the use of instruments that do less damage to the uterine walls. The comprehensive therapy that become the method of choice is operative lysis using hysteroscopy, which provides direct visualization of the adhesion. To prevent reccurrence, especially to patients planning to have subsequent pregnancies, timely surveillance of the next pregnancies for high risk patients should be performed at hospital, with complete work-ups. Lastly, evaluation of operative results and continuing education to explain prognoses to the patient should be also performed. (Med J Indones. 2013;22:121-6)
\end{abstract}

Keywords: Asherman syndrome, hysteroscopy, intrauterine adhesion

Asherman syndrome is an acquired condition characterized by the formation of adhesions in the uterine cavity. ${ }^{1,2}$ This condition may lead to menstrual aberrations, infertility, recurrent pregnancy loss, intrauterine growth retardation (IUGR), errors of placental implantation, and other complications associated with the uterine adhesion. ${ }^{3}$ Women with severe Asherman syndrome may require more than one imaging modality to establish the extent of disease and determine the prognosis for repair, and more than one approach to minimize recurrence of adhesions. Pre-operative assessment of Asherman syndrome may include hysterosalpingography (HSG), hysteroscopy, transvaginal ultrasonography, or saline infusion sonohysterography. Many pre-operative, intra-operative, and post-operative measures have been described to improve surgical outcomes, including hormonal manipulation with estrogen to induce endometrial proliferation, ultrasound-directed hysteroscopic lysis of synechia, and mechanical separation of the endometrium. This review aims to summarize recent guidelines and reviews on the management of Asherman syndrome.

\section{Etiology}

Asherman syndrome usually develops after the event of endometrial trauma, which most often follows curettage or shortly after pregnancy. ${ }^{2}$ Any insult severe enough to remove or destroy endometrium can cause adhesions. The gravid uterus is particularly susceptible to injury, especially between the second and fourth weeks postpartum. Inflammation or infection may also predispose patients to adhesions. In approximately $90 \%$ of cases, intrauterine adhesions relate to curettage for pregnancy complications, such as missed or incomplete abortion or retained products of conception. ${ }^{3,4}$

Adhesions can also develop after abdominal or hysteroscopic myomectomy, septum resection, or 
other uterine surgery. Poujade et al and Sentilhes found significant risk of uterine synechiae after several invasive methods of surgery, such as placement of several types of compression sutures and pelvic arterial embolisation, for post-partum hemorrhage. ${ }^{5,6}$

In the developing world, genital tuberculosis is considered an important cause of intrauterine adhesions. $^{2,4,7}$ Overall, the incidence of intrauterine adhesions is uncertain, but may be increasing. The risk of intrauterine adhesions associated with elective termination of pregnancy is generally low, but the prevalence and severity of adhesions may increase with the number of procedures. ${ }^{4}$

\section{Pathology}

There are three types of pathological tissues that compose intrauterine adhesions. The tissues are mucosal, fibromuscular, and connective tissue types, the most common of which is the avascular fibromuscular strands adjoining the uterine walls. In some cases, the adhesions may be accompanied by deep adenomyosis and/or adjoined by myometrium. Muscular adhesions are more dense and indicate a deficient endometrial basalis and a poorer prognosis. Some patients have only a sclerotic, atrophic endometrium and thus present with the worst prognosis. $^{3}$

\section{Diagnosis}

Diagnosing the syndrome can be difficult, because in some cases, the intrauterine adhesions can be asymptomatic; however, in most cases, there are clinical manifestations of menstrual disorders (hypomenorrhea, amenorrhea, and/or dysmenorrhea), pain, recurrent miscarriage, or infertility. A temporal relationship between symptoms and a predisposing event, the inability to pass a uterine sound, or a negative progestin challenge in amenorrheic women suggest the diagnosis. When suspected, hysterosalpingography and saline sonohysterography confirm the presence of intrauterine adhesions. In comparison to hysteroscopy, which is the gold standard, hysterosalpingography has approximately $80 \%$ sensitivity and specificity for the diagnosis of adhesions. A study that compared hysterosalpingography and sonohysterography with hysteroscopy concluded that the two methods of imaging were equally sensitive for detection of adhesions, but hysteroscopy is required to define the location and extent of disease. ${ }^{3}$ (Figure 1).

Hysteroscopy as a diagnostic tool can reveal a variety of findings. Central adhesive bands can appear as columns or bridges between the opposing walls of the cavity, dividing it into smaller irregular chambers of varying size and shape. Numerous classification systems have been proposed, but no system has gained wide acceptance or has prognostic value validated by prospective studies. Consequently, outcome studies are difficult to interpret and compare. ${ }^{1,8}$ March, in a systematic review on Asherman syndrome management, made a classification system based on the extent of the adhesion and degrees of severity. ${ }^{3,9}$ (Table 1)

\section{Management}

Until recently, the management of intrauterine adhesions is mostly focused on invasive methods and neglected the preventive measures prior to the development of adhesions. As the awareness of the risk factors of adhesions increase, there are several efforts made to find methods aiming to prevent adhesions in conditions predisposing to them. According to

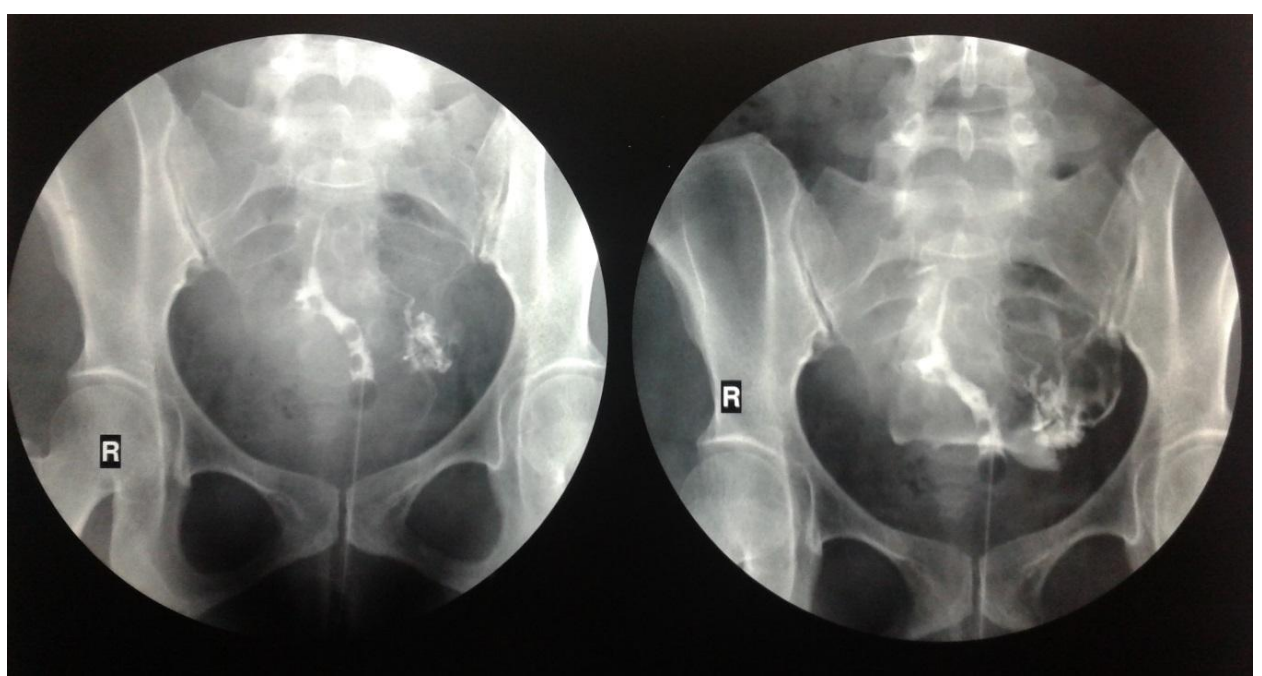

Figure 1. Intrauterine adhesions seen on hysterosalpingogram of a patient with Asherman syndrome 
Table 1. Classifications of intrauterine adhesions ${ }^{3}$

\begin{tabular}{ll}
\hline Class & Extent \\
\hline Mild & $\begin{array}{l}\text { Filmy adhesions in less than one-quarter of uterine cavity involved; thin or filmy adhesions } \\
\text { Ostial areas and upper fundus minimally involved or clear }\end{array}$ \\
Moderate & $\begin{array}{l}\text { Adhesions in one-quarter to three-quarters of uterine cavity involved; ostial areas and upper fundus } \\
\text { only partially occluded }\end{array}$ \\
Severe & More than three-quarters of uterine cavity agglutinated; ostial areas and upper cavity occluded
\end{tabular}

March, the principles critical to a successful approach to Asherman syndrome is encompassed by the acronym PRACTICE: PRevention, Anticipation, Comprehensive therapy, Timely surveillance of subsequent pregnancies, Investigation and Continuing Education. $^{3}$

\section{Prevention and anticipation}

Preventive measures are applied in different ways based on the predisposing events. In conditions requiring invasive method of evacuation, such as intrauterine fetal demise (IUFD), the gynecologist has to assess whether a less invasive method can be performed. A study by Zhang recommended prescription of misoprostol shortly after the occurrence of IUFD, because the likelihood of successful medical therapy decreases as the interval between demise and evacuation increases. ${ }^{10}$ March recommended the protocol for misoprostol begins with pre-treatment using ondansetron and hydrocodone/ ibuprofen tablet 1 hour prior to placing $800 \mathrm{mg}$ of misoprostol vaginally. If there is little or no response, the misoprostol is repeated in another 24 hours. Both the ondansetron and hydrocodone/ibuprofen tablet are repeated as necessary. If there has been a presumed passage of the products of conception an ultrasound is performed. If passage appears to be complete, $0.2 \mathrm{mg}$ methylergonovine maleate is prescribed orally every 4 hours for a total of six doses. ${ }^{3}$ If the ultrasound suggests retained products of conceptions (fetal tissue and/or placenta) after one dose of misoprostol, the regimen is repeated. If the treatment regimen fails, removal of the products of conceptions/POC under hysteroscopic guidance is recommended.

Other study found that breastfeeding women are at a higher risk of adhesions formation because they remain estrogen deficient for a long time, delaying endometrial proliferation. In these instances, the recommendation given was for nursing to be discontinued and estrogen to be prescribed. ${ }^{3}$

If a prior delivery had been complicated by retained $\mathrm{POC}$ or if the patient had undergone therapy for Asherman syndrome, uterine exploration at the time of delivery (rather than relying upon placental appearance to assure its completeness) offers prevention against subsequent post-partum complications related to retained POC. ${ }^{3}$ Several studies have reported the increasing risks of adhesions developing after routine curettage of retained placenta and placental fragments., ${ }^{3,11,12}$ March concluded that in order to reduce the number of curettages significantly, as well as the frequency of adhesions and other surgical complications, removal of retained placental by curettage should not be performed routinely. Sentilhes et al conduct a study on the effect of conservative treatment on placenta accreta on the complication rate, one of which is the intrauterine adhesions. Of the 96 patients $(73.3 \%)$ which are followed up after the treatment, eight women had severe intrauterine synechiae and were amenorrheic. This shows that successful conservative treatment for placenta accreta does not appear to compromise the patients' subsequent fertility or obstetric outcome. However, the possibility of intrauterine adhesion as one of the complications that can happen should be explained to the patients. ${ }^{13}$

Another study found that during 2 to 4 weeks after delivery, the execution of post-partum curettage is more likely to result in adhesions; meanwhile, within the first 48 hours after delivery, the uterus is much less vulnerable to adhesions formation after curretage. Because of the reasons above, it is recommended that removal of placental retention is done under hysteroscopic guidance. ${ }^{14}$ Wolfman recommended that in situations in which curettage is performed, ultrasound guidance should be used. ${ }^{15}$ If retained POC are suspected by ultrasound or hysteroscopy, medical therapy may cause their evacuation, thus reducing the need for curettage. ${ }^{3}$

Following removal, prophylactic measures against the development of adhesions are advised although their efficacy is unproven. Intravenous antibiotics are usually given during curettage and some recommend a brief course of oral therapy after surgery. Post-operative estrogen therapy may promote rapid endometrial 
regeneration and the short-term placement of a uterine stent may prevent adhesion formation by preventing the uterine walls from remaining in apposition early in the healing phase. Several studies encourage the use of estrogen therapy after currettage and IUD applications, however, this method needs to be assessed further through clinical trials. ${ }^{3}$ March also recommended other methods to decrease the frequency of post-operative adhesions formation, such as delaying prescription of gonadotrophin-releasing hormone agonist (GnRHa) prior to abdominal myomectomy and various types of hysteroscopic surgery for 7-8 weeks. This brief delay allows ovarian function to resume, initiating endometrium regrowth and allowing less traumatic fibroid removal at a time prior to the resumption of menses or tumour regrowth. ${ }^{16}$

Synechiae following uterine compression sutures in the management of major post-partum hemorrhage is also one of the most frequent causes of Asherman syndrome. Poujade et al in a retrospective observational study to women with post-partum hemorrhage that had uterine arterial embolisation and/or surgical uterine compression sutures found four of them women (26.7\%) developed uterine synechiae. This suggest that prevention methods of post-partum hemorrhage should be enacted to prevent the synechiae complications. ${ }^{17}$

Aside from the methods mentioned above, other methods that can be used are using mechanical surgical apparatus such as scissors rather than electrical or laser energy in incision of uterine septums, performing hysteroscopic myomectomy using the lowest effective power setting of the resectoscope and delivering the energy in the pure-cut mode, ${ }^{3}$ and introduction of new instrumentation and technologies that do less damage to the uterine wall. ${ }^{18}$

\section{Comprehensive therapy}

Hysteroscopy is considered the method of choice for treatment of intrauterine adhesions, because it is both safer and more effective than blind curettage. In many cases, adhesions' lysis can be accomplished using only the tip of the hysteroscope aided by the pressure provided by continuous infusion of distention media. When needed, an assortment of mechanical, electrosurgical, and laser-based instruments allows adhesions to be lysed or cut under direct vision. In general, best results are achieved when central adhesions are lysed first, moving from the lower uterine segment to the fundus and then to the margins of the cavity, gradually restoring normal cavity architecture. When disease is severe and anatomic landmarks are poorly defined, transabdominal ultrasonography or laparoscopy can help to maintain orientation and to limit the risk of uterine perforation. ${ }^{3}$ (Figure 2).

Various methods have been used to facilitate hysteroscopic surgery or to improve outcomes. In one randomized clinical trial examining the efficacy of vaginally administered misoprostol (200 $\mu \mathrm{g})$ for cervical softening before operative hysteroscopy, treatment reduced or eliminated the need for mechanical dilation and the incidence of operative complications. Various physical barriers, including both IUDs and balloon catheters, are commonly used as a means to maintain separation between the opposing layers of endometrium during the immediate post-operative interval. ${ }^{18}$ Orhue observed more frequent return of normal menses and higher conception rates in women receiving a catheter compared with IUD. ${ }^{19}$

Post-operative treatment with exogenous estrogens to promote rapid re-epithelialization and reduce risks of recurrent adhesions is frequently used, but its efficacy has not been established. A study by Cooper listed the complications of hysteroscopic adhesiolysis to include uterine perforation, fluid overload and electrolyte imbalance, hemorrhage, and infection; late complications include recurrent adhesions and uterine rupture in a subsequent pregnancy. March recommended a protocol of action based on the goals of the therapy. ${ }^{3}$ (Table 2).

The success rate for hysteroscopic surgery is quite good. A case series by Fernandez et al shows that among 23 women who had Asherman syndrome and were treated with more than two hysteroscopic operative procedures, more than $80 \%$ of them had either no adhesions at all or only mild adhesions, and the overall pregnancy rate was $40.9 \%$. Facilitation of the procedure in order to increase the cure rate and prevent reccurency is currently still studied. ${ }^{20}$

Table 2. Protocol for managing intrauterine adhesion ${ }^{3}$

\begin{tabular}{ll}
\hline Goals & Means \\
\hline Repair cavity & $\begin{array}{l}\text { Scissor lysis under direct } \\
\text { visualization }\end{array}$ \\
Prevent rescarring & Intrauterine stent \\
Promote healing & High-dose estradiol \\
Follow-up & $\begin{array}{l}\text { Hysteroscopy or } \\
\text { hysterosalpingogram } \\
\text { Architecture }\end{array}$ \\
Function & $\begin{array}{l}\text { Mid-cycle ultrasound of the } \\
\text { endometrium }\end{array}$ \\
\hline
\end{tabular}




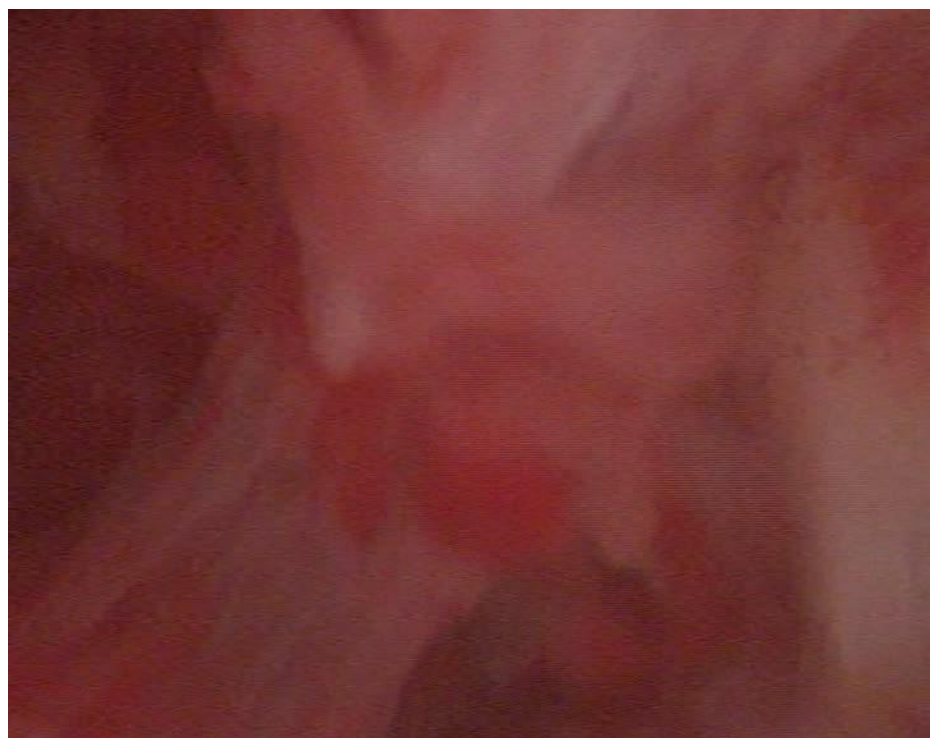

Figure 2. Intrauterine adhesions seen on hysteroscopy of a patient with Asherman syndrome

\section{Timely surveillance of subsequent pregnancies}

Monitoring of pregnancies among women with Asherman syndrome are divided among parameters associated with the syndrome and those which are not. A combination of delayed pregnancies, which are often caused by multiple misscariages, and delay in diagnosing the pregnancies often results in post Asherman syndrome' pregnancies occurring in women who are older and may have other factors needing treatment during early pregnancy. A study by Dwyer recommended for those who are at high risk of placenta accreta, which is one of the factors contributing to the development of the syndrome, that the delivery be planned to occur early on a weekday, times when the hospital, interventional radiology, laboratory and blood bank are fully staffed. ${ }^{21}$

\section{Investigation and continuing education}

According to the American Association of Gynecologic Laparoscopists, surgical results should be evaluated by hysterosalpingography or saline sonohysterography after menses. ${ }^{22}$ A second operation to lyse persistent or recurrent adhesions may be required when disease is severe. Alternatively, pressure lavage with normal saline under guidance of trans-vaginal ultrasonography can be used to hydro-dissect recurrent adhesions that are not particularly dense or extensive. ${ }^{4}$ Lysis using a balloon catheter under fluoroscopic control and local anesthesia or intravenous sedation also has been described.

Depending on the severity, fertility status and menstrual cycle of women with intrauterine adhesions who have underwent hysteroscopy lysis ranged from $70 \%$ to $90 \%$. Several studies have found that the conception and term delivery rates after successful hysteroscopic lysis of intrauterine adhesions have ranged between $25 \%$ and $75 \%$ and predictably, the prognosis is better for women with mild disease. ${ }^{4}$ Of the factors determining the return of fertility and conception rate, reformation of the synechiae is the most important one, as been shown by $\mathrm{Yu}$ et al in their study to evaluate the outcome of hysteroscopic adhesiolysis. In that study, the chances of conception after hysteroscopic adhesiolysis in women who remained amenorrheic were significantly lower than those who continued to have menses and the conception rate in women who had reformation of intrauterine adhesions ( 2 out of $17 ; 11.8 \%$ ) was significantly lower than that of women who had a normal cavity (26 out of $44 ; 59.1 \%$ ). ${ }^{23}$ Similar results have been shown in a study by Roy et al, who found here was significant higher likelihood of conception rate $(44.3 \%)$ in those who continued to have improved menstrual pattern compared to only $10 \%$ likelihood of conception in those who continued to have amenorrhea after adhesiolysis. ${ }^{24}$ From these results, we can deduct that education and continuing investigation of the fertility and conception rate should be performed to patients who have underwent hysteroscopic adhesiolysis.

In conclusion, based on the literatures that have been researched, the current comprehensive management of Asherman syndrome must include preventive measures for women who are at risk, comprehensive treatment based on lysis with hysteroscopy, timely surveillance 
of subsequent pregnancies to prevent reccurence of adhesions, and investigation of the surgical results and continuing education to the patient.

\section{REFERENCES}

1. Yu D, Wong YM, Cheong Y, Xia E, Li TC. Asherman syndrome-one century later. Fertil Steril 2008;89(4):759-79.

2. Myers EM, Hurst BS. Comprehensive management of severe Asherman syndrome and amenorrhea. Fertil Steril 2012;97(1): 160-4.

3. March CM. Management of Asherman's syndrome. Reprod Biomed Online. 2011;23(1): 63-76.

4. Fritz MA, Sperrof L. Female infertility. In: Fritz MA, Speroff L, editors. Clinical gynecologic endocrinology and infertility, 8th ed. Philadelphia (PA): Lipincott Williams \& Wilkins;2011.

5. Poujade O, Grossetti A, Mougel L, Ceccaldi P, Ducarme G, Luton D. Risk of synechiae following uterine compression sutures in the management of major postpartum haemorrhage. BJOG 2011;118(4):433-9.

6. Sentilhes L, Gromez A, Clavier E, Resch B, Verspyck E, Marpeau L. Fertility and pregnancy following pelvic arterial embolisation for postpartum haemorrhage. BJOG. 2010;117(1):84-93.

7. Burney RO, Schust DJ, Yao MWM. Infertility. In: Berek JS, editor. Berek \& Novak's gynecology, 14th ed. Philadelphia (PA): McGraw-Hill co.;2007. p.1050.

8. Berman JM, Intrauterine adhesions. Semin Reprod Med. 2008;26(4):349-55

9. March CM. Acquired intrauterine adhesions: Asherman's syndrome. In: Adashi, EY, Rock JA, Rosenwaks Z., editor. Reproductive endocrinology, surgery and technology. Philadelphia (PA): Lippincott-Raven;2006.1474-87

10. Zhang J, Gilles JM, Barnhart K, Creinin MD, Westhoff C, Frederick MM. A comparison of medical management with misoprostol and surgical management for early pregnancy failure. N Engl J Med. 2005;353(8):761-9.

11. Smith LFP, Ewings PD, Quinlan C. Incidence of pregnancy after expectant, medical, or surgical management of spontaneous first trimester miscarriage: long term followup of miscarriage treatment (MIST) randomised controlled trial. BMJ. 2009;339:b382.
12. Fontanarosa M, Galiberti S, Fontanarosa N. Fertility after non-surgical management of the symptomatic spontaneous first-trimester abortion. Minerva Ginecol. 2007;59(6):591-4.

13. Sentilhes L, Ambroselli C, Kayem G, et al. Fertility and pregnancy outcomes following conservative treatment for placenta accreta. Hum Reprod. 2010;25(11): 2803-10.

14. Dankert T, Vleugels M. Hysteroscopic resection of retained placental tissue. A feasibility study. Gynecol Surg. 2008;5:121- 4.

15. Wolman I, Altman E, Fait G, et al. Evacuating retained products of conception in the setting of an ultrasound unit. Fertil Steril 2009;91:1586-8.

16. Mavrelos D, Ben-Naji J, Davies A, Lee C, Salim R, Jurkovic D. The value of pre-operative treatment with $\mathrm{GnRH}$ analogues in women with submucous fibroids: a double blind, placebo-controlled randomized trial. Hum Reprod. 2010;25(9):2264-9.

17. Pujade O. Grosetti A, Mougel L, Ceccaldi PF, Ducarme G, Luton D. Risk of synechiae following uterine compression sutures in themanagement of major postpartum haemorrhage. BJOG. 2011;118(4):433-9.

18. Azziz, R. Role of reproductive surgeons and the Society of Reproductive Surgeons. Fertil Steril 2002;78(5):916-7.

19. Orhue AA, Aziken ME, Igbefoh JO. A comparison of two adjunctive treatments for intrauterine adhesions following lysis. Int J Gynaecol Obstet. 2003;82(1):49-56.

20. Fernandez H, Peyrelevade S, Legendre G, Faivre E, Deffieux X, Nazac A. Total adhesions treated by hysteroscopy: must we stop at two procedures?. Fertil Steril 2012;98(4):980-5.

21. Dwyer BK, Belogolovkin V, Tran L, et al. Prenatal diagnosis of placenta accreta: sonography or magnetic resonance imaging?. J Ultrasound Med. 2008;27(9):1275-81.

22. American Association of Gynecologic Laparoscopists. Practice guidelines for management of intrauterine synechiae. J Minim Invasive Gynecol. 2010;17:1.

23. Yu D, LiTC, XiaE, Huang X, Liu Y, Peng X. Factors affecting reproductive outcome of hysteroscopic adhesiolysis forAsherman's syndrome. Fertil Steril 2008;89(3):715-22.

24. Roy KK, Baruah J, Sharma JB, Kumar S, Kachawa G, Singh N. Reproductive outcome following hysteroscopic adhesiolysis in patients with infertility due to Asherman's syndrome. Arch Gynecol Obstet. 2010; 281(2):355-61. 